\title{
Working
}

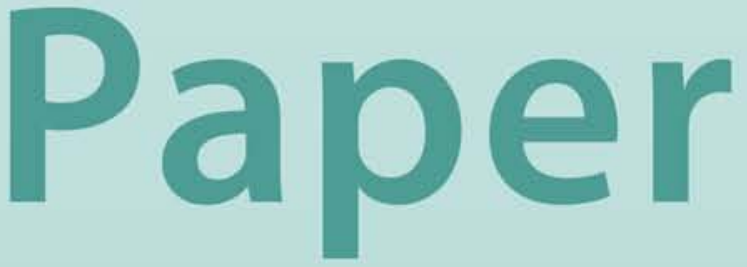




\section{Social Fractionalization, Political Instability, and the Size of Government}

Anthony Annett 


\title{
IMF Working Paper
}

Fiscal Affairs Department

\author{
Social Fractionalization, Political Instability, and the Size of Government \\ Prepared by Anthony Annett ${ }^{1}$ \\ Authorized for distribution by Richard Hemming
}

April 2000

\begin{abstract}
The views expressed in this Working Paper are those of the author(s) and do not necessarily represent those of the IMF or IMF policy. Working Papers describe research in progress by the author(s) and are published to elicit comments and to further debate.
\end{abstract}

This paper explores the relationship between the degree of division or fractionalization of a country's population (along ethnolinguistic and religious dimensions) and both political instability and government consumption, using a neoclassical growth model. The principal idea is that greater fractionalization, proxying for the degree of conflict in society, leads to political instability, which in turn leads to higher government consumption aimed at placating the opposition. There is also a feedback mechanism whereby the higher consumption leads to less instability as government consumption reduces the risk of losing office. Empirical evidence based on panel estimation supports this hypothesis.

JEL Classification Numbers: E62, O23

Keywords: fractionalization, political economy, size of government

Author's E-Mail Address: aannett@imf.org

\footnotetext{
${ }^{1}$ This paper is a condensed version of a chapter of the author's Ph.D thesis from Columbia University. The following people are thanked: Ben Broadbent, Sewin Chan, Luis Cubeddu, Gernot Doppelhofer, Duncan Foley, Geoff Heenan, Julie Kozack, Philip Lane, Puneet Manchanda, Ron Miller, Roberto Perotti, Xavier Sala-iMartin, and Dimitrios Thomakos.
} 


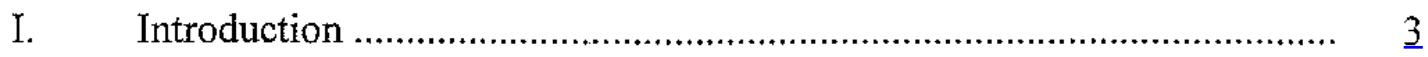

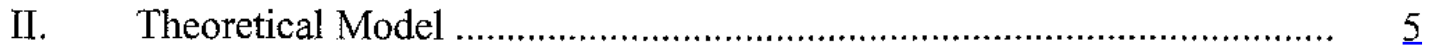

III. Measuring Fractionalization and Political Instability ......................... $\underline{10}$

A. The Concept of Fractionalization .......................................... 11

B. Ethnolinguistic Fractionalization .......................................... 11

C. Religious Fractionalization ............................................. 12

D. Political Instability ........................................................

IV. Empirical Results ..................................................................... 15

A. Econometric Methodology ................................................. 15

B. Government Consumption Equations .................................. $\underline{15}$

C. Systems Estimation .......................................................... 18

V. Conclusion …........................................................................... 21

Tables

1. OLS Government Consumption Equations ....................................... $\underline{22}$

2. Government Consumption and Political Instability Equations ............. $\underline{23}$

3. Fractionalization in TSLS Model …............................................. $\underline{24}$

4. Ethnic and Religious Fractionalization in a TSLS Model .................... 25

5. Other Definitions of Fractionalization ............................................. 26

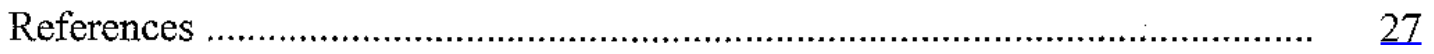




\section{INTRODUCTION}

When countries are heavily divided along ethnic, religious, communal, and regional lines, they are likely to experience bouts of political violence and are prone to the frequent breakdown of law and order. Clearly, serious conflict between competing groups, especially violent conflict, would be harmful to economic growth and the process of development. In such a divided country, can the government use expenditure to appease the competing groups and will this contain the potential conflict?

To isolate the sources of conflict, this paper follows the political economy literature in treating society as a collection of disparate groups, each concerned about its own interests at the expense of social welfare. Specifically, the degree of fractionalization within a country is measured along two dimensions, ethnolinguistic and religious. Although imprecise as a measure of the strength of competing groups, indices of fractionalization have the advantage of facilitating a broad cross-sectional empirical analysis with a large number of countries. The main hypothesis is that fractionalization leads inherently to greater levels of political instability and this imposes a political cost on the government as it risks being overthrown and losing any rents from being in power. Therefore the government attempts to placate the excluded groups by increasing the level of government consumption. This leads to a reduction in instability and thus buys the government a certain amount of insurance against being overthrown. Government consumption is thus used to reduce the level of "political risk."

A crucial assumption here is that the government does not use budgetary transfers to placate the other groups in society. This assumption is not unreasonable, given that many countries (especially in the developing world) lack the institutions necessary for a system of fiscal transfers and government consumption is often used for this purpose. For the period 1981-90, the ratio of government consumption to current central government expenditure (excluding interest payments) was 61 percent for all countries. This ratio varies substantially across countries depending on the level of development; it stands at 78 percent for low-income countries, 64 percent for middle-income countries and 36 percent for high-income countries. ${ }^{2}$ A large component of government consumption is the wage bill of government workers. Another way to view the effect of consumption on instability is to think of the government using consumption to transfer fiscal resources to the various groups in order to reduce the level of discontent in society.

Empirically, it is found that higher fractionalization leads to higher government consumption in a reduced form equation. In a simultaneous equations estimation with government consumption and political instability treated as endogenous, it is shown that the channel by which fractionalization affects government consumption is via political instability. Higher fractionalization leads to higher instability, while higher instability leads to higher government consumption. In turn, higher government consumption leads to lower political instability. Thus government consumption can indeed appease competing groups and reduce the level of conflict in a society divided along ethnic and religious lines.

The model presented in this paper is related to a number of strands which have developed independently in the political economy literature. Most of the previous work on political instability and fractionalization focuses on the impact of these variables on economic growth,

\footnotetext{
${ }^{2}$ Data are from the World Bank (1997). The classification of countries by level of development is taken from this source.
} 
while the literature on the determinants of government consumption has not incorporated these political economy aspects in any systematic manner.

One framework that could predict a positive relationship between fractionalization and government consumption is the common pool model. In this case, the government is inherently weak and each powerful group is able to extract resources from it. Given that society is composed of multiple self-interested groups who act noncooperatively, no single group has any incentive to constrain its demand for resources. Velasco $(1994,1995)$ suggests the common pool model as a reason for the perpetuation of fiscal deficits over time. Lane and Tornell (1996) and Tornell and Lane (1998) develop this idea in the context of a neoclassical growth model in which each group has common access to the capital stock. This not only leads to overconsumption and hence lower growth, but also a voracity effect in which groups actually increase more than proportionately their tate of appropriation after a positive shock to output.

The model presented in this paper posits an alternative link between fractionalization and government consumption, one which involves a strong central government strategically using government consumption to reduce the level of political risk. A society divided along ethnic or religious lines is potentially unstable; this channel has the advantage of making political instability endogenous.

There is a sizeable literature on the negative effect of political instability on economic outcomes. Barro (1991, 1996a) finds that political violence lead to lower growth in a cross-section of countries. Alesina and others (1996) conclude that while instability leads to lower growth, there is no evidence that low growth affects the propensity for government change. Possible reasons for this link include the induced uncertainty and the disruption in market activities deriving from the instability (see Perotti, 1996). The exact mechanism, however, by which instability reduces growth remains unspecified. Another approach to measuring political instability is to devise an index capturing the key elements of social and political unrest. Alesina and Perotti (1996) take this approach, arguing that the disorder created by this form of political instability adversely affects productivity and the return to investment. This framework is adopted here and a similar index of political instability is derived.

In related work, Blomberg (1996) argues that the government can use defence spending as a partial insurance against political instability; instability inhibits growth while increased military expenditure decreases instability. As well as the standard result that political instability reduces growth, the author also reports significant results in the other direction: higher growth reduces the probability of coups. The role of military expenditure in this model is similar to that of government consumption in the present paper: the logic of Blomberg (1996) is that the "stick" of military expenditure reduces instability. In this paper, the "carrot" of nonmilitary government consumption reduces the instability which arises from the existence of diverse groups in society.

The outline of the paper is as follows: Section 2 presents the basic theoretical model in which the relationship between fractionalization, political instability, and government consumption is developed within the context of a standard neoclassical growth model. Section 3 discusses the fractionalization and political instability indices used in this paper, especially in light of previous indices used. Section 4 is devoted to empirical testing and Section 5 concludes. 


\section{THEORETICAL MODEL}

The model presented here is an adaptation of the standard neoclassical one-sector endogenous growth model in which a policymaker chooses an intertemporal path for consumption subject to a capital accumulation equation. It is assumed that the economy comprises a number of groups, with the government controlled by a single group, or a coalition of different groups. All that matters is that the government does not represent every group in society. The most natural interpretation of consumption in this context is to think of it as the quantity of publicly provided goods ${ }^{3}$ provided by the government at any point in time.

The government derives utility from rents; this can be thought of as consumption allocated to the ruling group or as rents directly extracted from the economy's resources. ${ }^{4}$ The government's welfare at time 0 is the present discounted value of the sum of the instantaneous utility functions over time. Let private rents be denoted by $x_{t}$ and let the instantaneous utility function be $u\left(x_{t}\right)$; for tractability, it is assumed to be of the CRRA form so that

$$
u\left(x_{t}\right)=\frac{x_{t}^{1-\sigma}}{1-\sigma}
$$

where $\sigma$ is the inverse of the intertemporal elasticity of substitution.

Since the government is selfish, in the sense that it is concerned purely with the welfare of its members, it faces some probability of being overthrown. This may take the form of a democratic loss of office or an extraconstitutional seizure of power. The probability of losing power is associated directly with the degree of political instability in the country. This political dimension can be added to the neoclassical growth model in an intuitive manner. Assume that the government has a constant positive subjective discount rate $\theta$. Following Blomberg (1996), a second component will be added to the discount rate, one which reflects the possibility of the government losing power.

More specifically, assume that the government faces a stochastic process of overthrow, $\pi$, which is constant per unit time. If $\pi$ is assumed to be constant at each point in time then the introduction of this sort of uncertainty has the effect of raising the discount rate by $\pi$. The instability generated by the constant probability of overthrow means that the government becomes more impatient. Rather than treat it as an exogenous variable, it is assumed that the government can influence $\pi$ through its consumption choices and that the probability of overthrow is directly related to the proportion of total consumption appropriated as rents by the ruling cadre. Hence the government must choose the optimal path of rents $x_{t}$ and government consumption $c_{t}$ knowing that this choice will directly affect the probability of remaining in power that period. Formally,

$$
\pi^{\prime}\left(z_{t}\right)>0, z_{t} \equiv \frac{x_{t}}{x_{t}+c_{t}}
$$

\footnotetext{
${ }^{3}$ We can think either of public goods or publicly provided private goods; it makes no difference in the context of this model. For tractability, private consumption is ignored.

${ }^{4}$ One clear example of the latter would be funds deposited directly into the bank account of a kleptocratic leader.
} 
The intuition is straightforward: the excluded groups in society dislike the fact that the ruling cadre is deriving rents as opposed to providing consumption goods to benefit the populace as a whole. The level of government consumption can be interpreted as insurance against political instability and the ensuing probability of overthrow in the sense that it is possible to placate the excluded groups with government consumption. ${ }^{5}$

To complete the model, the equations of motion must be characterized. On the technological side, an AK model is assumed in which output $\left(y_{t}\right)$ is linear in a single factor, capital $\left(k_{t}\right)$, and $A$ represents the level of technology, so that:

$$
y_{t}=A k_{t}
$$

As always, the capital stock is a state variable and the government must decide how to allocate output between government consumption, investment, and rent-seeking. The accumulation equation can be written as:

$$
\dot{k}=A k_{t}-c_{t}-x_{t} .
$$

There is a second state variable in this model, which shall be called "political capital"; it is defined as the accumulated probability of being in power at time $t, p_{t}$. From the assumptions made about $\pi, p_{t}$ can be written as follows:

$$
p_{t}=e^{-\int_{0}^{t} \pi\left(z_{s}\right) d s} .
$$

Furthermore,

$$
\dot{p}=-p_{t} \pi\left(z_{t}\right)
$$

Just as the government must choose between consuming or investing in physical capital, so it faces an intertemporal trade-off between extracting rents and building up political capital. The optimization problem is one involving two control variables and two state variables and can be written succinctly as

$$
\max E_{0} \int_{\left\{c_{t}, x_{t}, \hat{x}_{t}\right\}}^{\infty} e^{-\int_{0}^{t} \pi\left(\frac{x_{s}}{x_{s}+c_{\theta}}\right) d s}\left(\frac{x_{t}^{1-\sigma}}{1-\sigma}\right) e^{-\theta t} d t
$$

subject to $k_{0}>0,(4)$ and (6). In solving this problem, the two control variables are re-defined as $z_{t}$ and $w_{t}$ where $w_{t} \equiv c_{t}+x_{t}$. The government chooses the total level of consumption and

\footnotetext{
${ }^{5}$ McGuire and Olson (1996) argue along similar lines, claiming that even if a ruler is concerned only with personal rents, she has an incentive to provide public goods. In the authors' model, public goods are required to produce productive private goods which in turn yield valuable revenues to the ruler.
} 
the allocation between rents and public goods. Note that (7) has an intuitive interpretation: the government maximizes the expected utility of rents at each future time period, where the expected value depends on the probability of being in power at each future date. The political preferences have the effect of turning the problem into one with an endogenous discount rate. ${ }^{6}$

The following first-order conditions can therefore be derived, where $\lambda_{t}$ and $\mu_{t}$ are the co-state variables for physical and political capital respectively. ${ }^{7}$ The growth rate of a variable will be denoted by $\gamma$.

$$
\begin{gathered}
p_{t} z_{t} u^{\prime}\left(x_{t}\right)=\lambda_{t} \\
w_{t} u^{\prime}\left(x_{t}\right)=\mu_{t} \pi^{\prime}\left(z_{t}\right) \\
\gamma_{\lambda}=-(A-\theta) \\
\frac{u\left(x_{t}\right)}{\mu_{t}}=\left(\theta+\pi_{t}\right)-\gamma_{\mu} .
\end{gathered}
$$

There are two transversality conditions which must be satisfied, namely:

$$
\begin{aligned}
& \lim _{t \rightarrow \infty} k_{t} \lambda_{t} e^{-\theta t}=0 \\
& \lim _{t \rightarrow \infty} p_{t} \mu_{t} e^{-\theta t}=0 .
\end{aligned}
$$

For this problem to give a meaningful solution,the following restriction must be imposed on the utility function:

$$
u\left(x_{t}\right)>0 .
$$

Given the particular utility function specified in (1), the condition that $\sigma<1$ needs to be imposed. ${ }^{8}$ Equations (8) and (10) can be used to derive the growth rate of rents and consumption in this

\footnotetext{
${ }^{6}$ There is a large literature on endogenous discount rates, beginning with Uzawa (1968). Obstfeld (1990) works out a complete model for the case of one control variable. The model is also similar in nature to the endogenous fertilty models of Becker and Barro (1988) and Barro and Becker (1989).

${ }^{7}$ A technical appendix, providing a detailed derivation of the steady-state plus an analysis of transitional dynamics, is available upon request from the author.

${ }^{8}$ A negative utility function in this framework would have the effect of placing negative weight on the future, thus leading the government to set $z=1$ today. This is a particular feature of models with endogenous discount rates.
} 
economy. First, the condition that $\gamma_{z}=0$ is imposed; since $\pi$ must be constant in steady-state, the growth rate of $z_{t}$ must be zero. This has the implication that consumption and rents grow at the same rate; namely, $\gamma_{w}=\gamma_{x}=\gamma_{c}$. Noting that $\gamma_{p}=-\pi$ in steady-state, it follows that the common growth rate can be written as follows:

$$
\gamma_{c}=\gamma_{x}=\frac{1}{\sigma}[A-(\theta+\pi)]
$$

This is the standard solution for an AK model; it implies that the growth rate of consumption (either private rents or general government consumption) is independent of the level of capital (see Barro and Sala-i-Martin, 1995). This equation can be rearranged in the following way:

$$
A=\sigma \gamma_{c}+\theta+\pi
$$

The left-hand side represents the return to investment while the right-hand side represents the return to consumption. Given that $\pi>0$ this implies that the return to consumption exceeds the return under the modified golden rule. The intuition is straightforward: the possibility of overthrow biases the government's choice towards present consumption instead of investment. This leads to a Pareto-inefficient outcome. ${ }^{9}$

The levels solution shall now be derived. Manipulating equations (9) and (11) yields the following statement about the steady-state value of $z$ :

$$
z \pi^{\prime}(z)=\frac{1-\sigma}{\sigma}[\theta+\pi(z)]-\frac{(1-\sigma)^{2}}{\sigma} A
$$

Given the assumption that $\sigma<1$, the right-hand side of (17) is always positive .

Finally, the growth rate of capital can be written as follows:

$$
\gamma_{k}=A-\phi, \phi \equiv \frac{w_{t}}{k_{t}}
$$

Given that the growth rate of consumption (rents) does not depend on the level of capital, it is possible to describe consumption (rents) at time $t$ as a function of initial consumption (rents). It is straightforward to show that this implies a proportional relationship between consumption (rents) and capital. If not, $\phi$ would not be constant in steady-state. Applying this result, and appealing to the linear production function in (3), it is clear that $\gamma_{x}=\gamma_{c}=\gamma_{w}=\gamma_{k}=\gamma_{y}$.

Setting $\gamma_{x}=\gamma_{k}$, the equilibrium level of $\phi$ can be solved for as follows:

$$
\phi=\frac{1}{\sigma}(\theta+\pi)-\frac{1-\sigma}{\sigma} A
$$

The solution can now be fully characterized by equations (17) and (19). Equation (17) allows for the retrieval of the equilibrium value of $z_{t}$ and plugging this into (19) gives $\phi_{t}{ }^{10}$

\footnotetext{
${ }^{9}$ Blomberg (1996) derives the same result in his model.

${ }^{10}$ This is the only possible solution to this dynamic model. All other paths can be ruled out either
} 
To derive clearer results, a functional form on $\pi\left(z_{t}\right)$ needs to be imposed; in line with Blomberg (1996), the following linear specification is assumed: ${ }^{11}$

$$
\pi\left(z_{t}\right)=\alpha+\beta z_{t} .
$$

The steady-state values of the main variables can be written as follows:

$$
\begin{gathered}
z^{*}=\frac{1-\sigma}{\beta(2 \sigma-1)}[(\theta+\alpha)-(1-\sigma) A] \\
\phi^{*}=\frac{[(\theta+\alpha)-(1-\sigma) A]}{(2 \sigma-1)} \\
\pi^{*}=\frac{\sigma}{(2 \sigma-1)} \alpha+\frac{1-\sigma}{(2 \sigma-1)}[\theta-(1-\sigma) A] \\
\gamma=\frac{\sigma}{(2 \sigma-1)} A-\frac{1}{(2 \sigma-1)}(\theta+\alpha) .
\end{gathered}
$$

The optimal response of these variables to an exogenous increase in the probability of overthrow, defined here as in increase in $\alpha$ or $\beta$, will now be considered. In terms of the effects of an exogenous increase the risk of overthrow on the government's choice of $z_{t}$, there are two possibilities, depending on the preferences of the government. It could either tespond by decreasing the level of $z_{t}$ in an attempt to buy insurance against the increased political instability or it could decide that, given that it faces a higher probability for being ousted from power, it should seize more rents today.

The comparative statics for a change in $\beta$ are particularly straightforward to analyze:

$$
\frac{\delta z^{*}}{\delta \beta}<0 ; \frac{\delta \phi^{*}}{\delta \beta}=\frac{\delta \pi^{*}}{\delta \beta}=\frac{\delta \gamma}{\delta \beta}=0 .
$$

This is because $\beta z_{t}$ is a positive constant so an increase in $\beta$ will necessarily be associated with a decrease in $z_{t}$, leaving $\pi_{t}$ unchanged. This has the property that $\pi_{t}$ will always remain constant when $\beta$ changes. Total consumption in the economy is unchanged: the only effect is a shift in the composition of $w_{t}$ from rents to government consumption. The reduction in $z_{t}$ is such that it completely counteracts the effect of the higher $\beta$ and hence $\pi$ is unchanged. This also ensures that there is no change in the growth rate.

The effect of an increase in the constant term, $\alpha$, is more ambiguous. We can derive the following comparative static results:

by the fact that they hit a boundary or by a violation of the transversality condition.

${ }^{11}$ None of the results depend specifically on the linear functional form. 


$$
\frac{\delta z^{*}}{\delta \alpha}=\frac{1-\sigma}{\beta(2 \sigma-1)} ; \frac{\delta \phi^{*}}{\delta \alpha}=\frac{1}{2 \sigma-1} ; \frac{\delta \pi^{*}}{\delta \alpha}=\frac{\sigma}{2 \sigma-1} ; \frac{\delta \gamma}{\delta \alpha}=\frac{-1}{2 \sigma-1}
$$

The signs of the above derivatives will depend on whether $\sigma$ is greater or less than one half. If $0<\sigma<\frac{1}{2}$ then $\frac{\delta z^{*}}{\delta \alpha}<0, \frac{\delta \phi^{*}}{\delta \alpha}<0, \frac{\delta \pi^{*}}{\delta \alpha}<0$, and $\frac{\delta \gamma}{\delta \alpha}>0$. In this case, the government reacts to an exogenous increase in $\alpha$ by reducing both $z_{t}$ and $w_{t}$; this reduces the probability of overthrow and actually increases growth in the economy. So instead of switching consumption from rents to government consumption, the government instead switches resources towards investment. If, on the other hand, $\frac{1}{2}<\sigma<1$ then $\frac{\delta z^{*}}{\delta \alpha}>0, \frac{\delta \phi^{*}}{\delta \alpha}>0$, $\frac{\delta \pi^{*}}{\delta \alpha}>0$, and $\frac{\delta \gamma}{\delta \alpha}<0$. Here, the government is deciding to increase appropriation of rents. Total consumption is increasing, as is the probability of overthrow. Hence, growth is lower in this scenario. The government, responding to the higher exogenous probability of overthrow, responds by choosing present consumption at the expense of investment.

It is possible to view the effect of an increase in the number of excluded groups through the comparative static exercise of an increase in $\alpha$ or $\beta$. The idea is that a more fractionalized country is exogenously more unstable. One way to model a more fractionalized country is through a higher $\alpha$; holding everything else constant, a higher degree of fractionalization (more excluded groups in the economy) leads directly to higher political instability and hence a higher probability of overthrow. It is also possible to model an increase in fractionalization as an increase in $\beta$; the intuition here is that it is harder in terms of political capital to appropriate a fixed proportion of total consumption as rents in more fractionalized countries. In other words, the marginal cost of appropriating rents is greater in more fractionalized societies. A corollary is that the marginal benefit of "bribing" or "buying insurance" using government consumption is higher in more fractionalized countries. ${ }^{12}$ There is no single way to model fractionalization; this approach has the advantage of simplicity and consistency with the model.

In terms of the empirical predictions of the model, the clearest results pertain to the level of government consumption. At the most basic level, higher levels of government consumption should be observed in more fractionalized economies. In this model, higher fractionalization leads directly to greater levels of political instability and this is compensated for by higher levels of government consumption. This higher government consumption in turn indirectly reduces political instability. No clear predictions emerge for growth: if the $\beta$-mechanism is the channel of interest, then there should be no relationship between growth and fractionalization as the direct and indirect effects on political instability cancel exactly. The empirical section of this paper will focus exclusively between the interaction between fractionalization, political instability, and government consumption.

\footnotetext{
${ }^{12}$ An alternative viewpoint is that, if a highly fractionalized country means each opposition group is really weak, it may be that the political cost of appropriating rents will be decreasing in fractionalized countries. Ultimately, it remains an empirical issue.
} 


\section{Measuring Fractionalization and Political Instability}

\section{A. The Concept of Fractionalization}

This paper uses a number of indices of fractionalization, measured along ethnolinguistic and religious scales, as proxies for the number of competing groups in society. One weakness of this approach is that such a measure cannot distinguish between groups which are powerful and groups which are weak. This is the motivation employed by Lane and Tornell (1996) for eschewing measures of fractionalization as proxies for competing groups within society. In the present case, which focuses on instability, such indices may indeed be reasonable proxies for the degree of conflict within society. The intuition is that more fractionalized countries are inherently more prone to instability, and this necessitates placation through higher levels of government consumption. ${ }^{13}$ Of course, the indices will not measure the "intensity of conflict" between groups and this will remain a fundamental weakness.

The indices developed in this paper are defined as follows. For a given number of groups in society, the index measures the probability that two randomly selected individuals from the country in question will not belong to the same group. Formally, it can be calculated from the following formula:

$$
\text { Fractionalization }=1-\sum_{i=1}^{M}\left(\frac{n_{i}}{N}\right)^{2}, i=1, \ldots ., M
$$

$N$ is the total population and $n_{i}$ is the number of people belonging to the $i$-th group. Specifically, two such indices will be defined, ethnolinguistic fractionalization and religious fractionalization. The former divides the country into ethnolinguistic groups while the latter concentrates on different religious groupings. Given data availability, these seem to be reasonable proxies for measuring the importance, though not the intensity, of group affiliation within each country. A further problem is that these indices will have no time-variance, and the assumption that they only change slowly over time will be maintained. This is important, because the empirical section described in Section 4 will use panel data from three decades.

\section{B. Ethnolinguistic Fractionalization}

A number of researchers have worked with indices of ethnolinguistic fractionalization in the past. Mauro (1995) presented such an index, derived from the World Handbook of Political and Social Indicators by Taylor and Hudson (1972); this index in turn is based on data from 1960 and was constructed in the Soviet Union for the Atlas Narodiv Mira. ${ }^{14}$ Taylor and Hudson (1972) also consider two other indices of ethnolinguistic fractionalization. The second index was derived by Muller (1964), in a comprehensive study of the world's living languages. The third of the indices has the fewest number of countries and derives from Roberts (1962), from a study of second languages in Asia, Africa, and Latin America. Researchers in economics have tended to use the

${ }^{13}$ This is the motivation for postulating a positive relationship between fractionalization and the $\alpha$ and $\beta$ parameters in the previous section.

${ }^{14}$ Moscow: The N.N. Miklukho-Maklaya Institute of Ethnography of the Academy of Sciences, Department of Geodesy and Cartography of the State Geological Committee of the USSR, 1964 
Soviet index, given the larger sample size, and the argument by Taylor and Hudson (1972) that the data are free from ideological bias. Furthermore, Easterly and Levine (1997) argue that the other two measures are flawed as they omit certain key groups within countries.

A number of papers in recent years have used the Soviet index to explore the effects of ethnolinguistic fractionalization on the overall macroeconomic environment. Canning and Fay (1993) argue that a more fractionalized population leads to lower productivity growth. Easterly and Levine (1997) focus on low growth rates in Sub-Saharan Africa. They find that fractionalization of society along ethnic lines is associated with low schooling, political instability, underdeveloped financial institutions, distorted foreign exchange markets, high government deficits, and poor institutional quality. They conclude that such results provide evidence of strong rent-seeking behavior and inability to find consensus on the provision of public goods in highly fractionalized economies. Controlling for other variables, Sala-i-Martin (1997) argues that ethnolinguistic fractionalization is not robustly correlated with growth. In related work, Alesina, Baqir, and Easterly (1997) address the issue of ethnic fractionalization and the provision of local public goods in US cities, counties, and metropolitan areas. They conclude that more ethnically diverse regions are associated with higher spending and deficits per capita, but with lower spending shares on basic public goods like education. Along similar lines, Kuijs (2000) presents international evidence that more divided societies spend less on public goods.

This paper starts afresh and builds a new index of ethnolinguistic fractionalization. The source of the data is the World Christian Encyclopedia (Barrett, 1982) which provides an extremely detailed breakdown of the ethnolinguistic groups within each country. It al so has the advantage of coming from the same source as the data on religious fractionalization. The methodology is simply to include as many groups as possible at the most detailed level of breakdown. The larger the number of groups in a country, the higher the value of the resulting index. If 100 percent coverage can be achieved with the most detailed breakdown of ethnolinguistic groupings, this is the methodology adopted. Otherwise, a more aggregated group is taken. ${ }^{15}$

This new index of ethnolinguistic fractionalization has a number of advantages over the previous indices, including the care taken to include as many groups as possible, the more recent data, and the larger sample size. ${ }^{16}$ In contrast, the Soviet measure has data for only 119 countries in this sample. The other indices are even worse: the Muller index contains 102 countries in the sample, while the Roberts index reports only 47 . From this point, the Soviet, Muller, and Roberts indices shall be denoted Index 1, Index 2, and Index 3 respectively; The correlation between the present index and the Taylor-Hudson indices are as follows: 0.84 for Index 1, 0.66 for Index 2, and 0.85 for Index 3. For the sake of comparison, the correlation between Index 1 and Index 2 is 0.83 , and the correlation between Index 2 and Index 3 is 0.93 .

\section{Religious Fractionalization}

Apparently, there has been no attempt in the literature to develop an index of religious fractionalization with a view to analyzing its impact on macroeconomic variables. ${ }^{17}$ The index of

\footnotetext{
${ }^{15}$ Actually, this rarely arose as a significant problem, given the highly detailed level of the data. ${ }^{16}$ The values of this index for 150 countries are available on request from the author.

${ }^{17}$ Some work has been done on the impact of religious affiliation and the size and efficiency of government. La Porta and others (1998) analyze the effect of religious affiliation and size and
} 
religious fractionalization used in this paper, simply measures the probability that two randomly drawn people in a specific country will not belong to the same religious group, and hence measures the degree of fractionalization in society along a different dimension. Once again, the data used in compiling this index comes from the World Christian Encyclopedia (Barrett, 1982) and all the information pertains to the early $1980 \mathrm{~s} .{ }^{18}$ Any religion listed by Barrett (1982) as a distinct religion in a given country is included in the index. The only religion which is disaggregated is Christianity: the subdivisions include Catholicism ${ }^{19}$, Protestantism ${ }^{20}$, Eastern Orthodoxy, Indigenous Christianity ${ }^{21}$, and Crypto-Christians, ${ }^{22}$ Other groupings include Islam, Hinduism, Buddhism, Judaism, Tribal religions, Shintoism, Chinese folk religion, as well as a plethora of minor religions (such as Baha'i). Furthermore two secular categories are included: Nonreligious and Atheist. The data for the latter normally derives from membership of communist parties in the country in question.

The mean value of the religious fractionalization index is 0.38 . The simple correlation of the indices of ethnic and religious fractionalization yields a coefficient of 0.39 , suggesting a positive relationship between the indices but also confirming that each index captures a different dimension to the fractionalization within each country.

For the sake of comparison, and to assess robustness, a supplementary index of religious fractionalization called Index 4 has been compiled. The data used is from a different source ${ }^{23}$ and at a much less disaggregated level. Only ten categories are included: Catholicism, Protestantism, Eastern Orthodoxy, Islam, Hinduism, Buddhism, Judaism, African indigenous, Chinese folk, and Official Atheism. The raw correlation between the two indices of religious fractionalization is 0.89 .

Since religious and ethnic fractionalization represent two dimensions to the divisions within society, it makes sense to combine them. Hence the index of fractionalization is defined as one half times the value of ethnolinguistic fractionalization plus one half times the value of religious fractionalization: this index will be the principle proxy for conflict between competing groups in this paper. ${ }^{24}$ From now on, the term fractionalization shall be taken to mean this combined index.

quality of government. The present study emphasizes religious division and does not consider the potential effects of religious affiliation.

${ }^{18}$ Barto (1996b) argues that the data does not significantly change over time.

${ }^{19}$ Includes non-Roman catholics.

${ }^{20}$ Includes all protestant denominations.

${ }^{21}$ Usually associated with African and Caribbean countries.

${ }^{22}$ This group is a residual, and estimate of the number of clandestine christians in countries which do not grant religious freedom. It is included in the index as a separate group, as there is no way (from the data) of apportioning this group between the other denominations. It is only an issue in a small number of countries, and may serve as a proxy for the enhanced religious tensions in these countries.

${ }^{23}$ The Encyclopedia Britannica Online.

${ }^{24}$ Values of the religious and combined (ethnolinguistic and religious) fractionalization indices for 148 countries are available upon request from the author. 


\section{Political Instability}

There are a number of different approaches to the quantification of political instability. Unlike Londegran and Poole (1991), Blomberg (1996) and Alesina and others (1996), instability in this paper is not equated with the propensity of observing changes in government. Rather, the second approach is adopted and an index of political unrest is devised. Following other researchers in the area, a single index of political instability encompassing a number of different factors is created. This is precisely the methodology employed by researchers such as Hibbs (1973), Vanieris and Gupta (1986), Gupta (1990), Alesina and Perotti (1996), and Perotti (1996).

The idea is that these factors capture different dimensions of political instability in the country. The following nine dimensions are employed: (1) genocidal incidents involving communal victims or mixed communal and political victims (COMPOL), measured as a dummy variable (2) the occurrence of a civil war, measured as a dummy variable (WARCIV), (3) the number of assassinations per thousand population (ASSASS), (4) the number of extraconstitutional or forced changes in the top government elite and/or its effective control of the nation's power structure (COUPS), (5) the number of illegal or forced changes in the top government elite, any attempt at such change, or any successful or unsuccessful armed rebellion whose aim is independence from the central government (REVOLS), (6) violent demonstrations or clashes involving more than a hundred citizens involving the use of physical force (RIOTS), (7) the number of major government crises, where a crisis is defined as any rapidly developing situation threatening to bring the downfall of the present regime, excluding instances of revolt aimed at overthrow (CRIS), (8) the number of times in a year that a new premier is named and/or 50 percent of the cabinet posts are occupied by new ministers (CABCHG), and (9) the number of basic alterations in a state's constitutional structure, the extreme case being the adoption of a new constitution that significantly alters the prerogatives of the various branches of government (CONSTCHG). ${ }^{25}$

These factors measure political instability along a number of different dimensions, all threatening the survival of the present government in some way. From the point of view of the model, it is necessary to develop an index of political instability which directly captures those aspects of social disruption which will lead the government to trade-off private rents in order to devote resources towards the alleviation of this instability. The statistical methodology employed in deriving such an index is that of factor analysis. The index, which is called INS, is defined as follows:

$$
\begin{gathered}
I N S=0.61 * W A R C I V+0.57 * C O M P O L+0.29 * A S S A S S+0.10 * \text { CRIS } \\
+0.07 * R E V O L S+0.06 * \text { RIOTS }+0.01 * \text { COUPS }+0.01 * C A B C H G+0.01 * \text { CONSTCHG }
\end{gathered}
$$

The factor analysis technique is designed to reduce the dimensionality of a variable by describing linear combinations of those variables which contain most of the information. In essence, the technique recovers the latent original variable by identifying a small number of common factors which linearly reconstruct the original variables. Vanieris and Gupta (1986) claim that there is "general agreement among students of the relevant literature" that there are two dimensions to political instability which can be disentangled by factor analysis. These dimensions represent the less and more violent events, the former placing weight on such variables as riots and

${ }^{25}$ These variables, including the definitions, are taken directly from the dataset of Easterly and Levine (1997). 
demonstrations, the latter emphasizing those elements which result in deaths. Hibbs (1973) dubbed these factors "collective protest" and "internal war" respectively. This is indeed the pattern found with the data in question: the instability variable here reflects the more violent "internal war" factor. In this sense, the index should be interpreted primarily as one representing political violence.

One advantage of INS is that, unlike previous indices, it is time-varying with average decade values for the sixties, seventies, and eighties. Data availability constrains the series to include only 108 countries. ${ }^{26}$

\section{EMPIRICAL RESULTS}

\section{A. Econometric Methodology}

The goal of this section is to explore the data for evidence in favor of the hypothesis forwarded in Section 2 using data on fractionalization, instability, and government consumption. Pooled time-series cross-section data will be used, with three time observations corresponding to the decade averages for the 1960s, 1970s, and 1980s. The ten year average is used to remove any short-term cyclical patterns in government consumption. To allow for decade-specific effects, decade dummies are included in each equation. The following sequence is adopted: first, single-equation estimation for government consumption is presented to ascertain the importance of fractionalization. Following from this, systems estimation techniques are utilized, treating both government consumption and political instability as endogenous.

The model of Section 2 argues that the government appropriates rents directly to benefit its own group and provides government consumption to the benefit of excluded groups. It is implicitly assumed that rents take the form of a direct transfer and do not show up in government consumption. Clearly, it may be the case that some rents are included within government consumption. Unfortunately, this is impossible to disentangle empirically. Nonetheless, it is not unreasonable to posit that the bulk of government consumption benefits a larger group of citizens than the government faction alone. ${ }^{27}$ In an empirical study, Rodrik (1997b) finds no effect of resource rents on government consumption, and concludes that government consumption (in particular public employment) is driven more by social insurance considerations. ${ }^{28}$

\section{B. Government Consumption Equations}

For most of the equations, the dependent variable employed will be the real share of nonmilitary government consumption to GDP. This is measured as the share of government consumption in GDP, measured in 1985 international prices from the Heston-Summers data set $^{29}$ minus the ratio of government expenditure on defense (deflated by the investment price) ${ }^{30}$ to real GDP from

${ }^{26}$ Values for this index are available upon request from the author.

${ }^{27}$ If the data were available, it would be possible to test compositional effects, along the lines of Alesina, Baqir, and Easterly (1997).

${ }^{28}$ Rodrik deals with economic, not political risk.

${ }^{29}$ Penn World Tables 5.6.

${ }^{30}$ The investment deflator is probably an accurate proxy for the military goods deflator. 
the Barro-Lee data set. ${ }^{31}$ The reason for excluding military spending is straightforward: one may postulate that military expenditure is higher in more unstable countries, for reasons not accounted for by the model. There are a number of reasons for choosing to work with the Heston-Summers data. Most of the previous work in recent years on the determinants of government consumption has utilized this data source. A number of researchers, such as Ram (1987) and Rodrik (1996) maintain that the Heston-Summers data is superior to the more conventional data on government shares for the problem at hand given that the conventional data suffer from problems created by the differing relative price of government purchases across countries. Without making this adjustment, the actual size of government in poorer countries is biased downwards.

Table 1 estimates a number of basic government consumption equations. It is necessary to produce a number of control variables: these will be the variables considered important in previous work in the field. There is a burgeoning literature in recent years on the determinants of the size of government; most of this work has focused on the importance of economic and demographic variables. ${ }^{32}$ The equations in Table 1 , as will be the case with all equations in this paper, include decade dummies. To be able to compare these results with the results of the structural equations in the next section, the sample size is constrained to the 108 countries for which data is available on political instability.

In terms of control variables, the age dependency ratio is one of the most common demographic variables in the literature, based on the idea that a higher proportion of young and old people in the population leads to greater demand for publicly provided services, especially health care and education. A higher rate of urbanization is postulated to lead to a higher demand for government services. Adding a political economy dimension, it is plausible to argue that the government is likely to favor the urban over the rural community. Alesina and Spolaore (1995) argue that there are economies of scale in the provision of public goods. Population is included as a proxy for country size; this variable is significant in Alesina and Wacziarg (1997).

In terms of economic variables, a lot of attention has been accorded to the role of income per capita in explaining the size of government. One of the oldest hypotheses in the literature is Wagner's Law: this states that the demand for government services is income elastic so a higher GDP per capita is expected to lead to a higher share of government consumption in GDP. The reasoning behind this is that either government consumption is a luxury good or the administrative and regulatory costs increase with the level of economic development.

Cameron (1978) argued that more open economies were associated with larger government as measured by the share of consumption in GDP. Rodrik $(1995,1996,1997 \mathrm{a})$ argues that the government sector insulates the economy from the destabilizing effects of external shocks. According to this logic, countries with higher exposure to external risk tend to have larger governments. Therefore the positive coefficient on openness in a reduced form government consumption equation stems from the fact that more open economies are exposed to external risk, and in these economies, the government uses its own consumption as a buffer against this risk.

\footnotetext{
${ }^{31}$ This is exactly the way that Barro $(1991,1996$ a) nets defense spending out of government consumption in order to measure that component of government consumption which does not enhance productivity (to this end he also excludes expenditure on education). ${ }^{32}$ See for example Tait and Heller (1982), Ram (1987), Lindauer (1988), Heller and Diamond (1990), Kraay and van Rijckeghem (1995), Rodrik (1995), Rodrik (1996), Commander, Davoodi, and Lee (1997), and Alesina and Wacziarg (1997).
} 
Rodrik (1996) derives a theoretical measure of external risk, which is defined as the degree of openness multiplied by the standard deviation of terms of trade shocks: this is the definition of external risk in this paper.

Table 1 considers the significance of fractionalization, holding fixed the aforementioned control variables. Equation 1 shows that fractionalization (the linear average of the ethnolinguistic and religious fractionalization indices) is positive but completely insignificant when regional dummies are excluded. ${ }^{33}$ When the three regional dummies are entered into the model, the results change dramatically: in separate equations the point estimates on fractionalization, ethnolinguistic fractionalization, and religious fractionalization are all positive and significant ${ }^{34}$ This is because there are significant regional patterns to both government consumption and fractionalization and therefore the exclusion of these regional effects may cause omitted variable bias in the fractionalization coefficients. For the remainder of the paper, regional dummies will be included in all equations.

In terms of magnitude, increasing fractionalization by one standard deviation leads to an increase in government consumption of 0.16 standard deviations: given that the standard deviation of government consumption is 7.87 , a one standard deviation increase in fractionalization will increase government consumption by 1.29 percentage points. ${ }^{35} \mathrm{~A}$ one standard deviation in ethnolinguistic fractionalization will increase government consumption by 0.09 standard deviations; the equivalent number for religious fractionalization is 0.15 . It can be concluded, as predicted by the theoretical model, that higher levels of fractionalization lead to higher levels of government consumption. Furthermore, this result holds up among both dimensions of fractionalization although the results, both qualitatively and quantitatively, seem to be weaker for ethnolinguistic than for religious fractionalization.

As for the control variables, the age-dependency ratio and openness are not significant in any of the equations. Real income per capita is negative and strongly significant in every equation: this conclusion is in line with Rodrik (1996). The point estimate on the standard deviation of the terms of trade is negative and significant while the measure of external tisk is positive and significant as predicted by the hypothesis of Rodrik (1996). Equation 5 adds the urbanization rate and a socialist dummy ${ }^{36}$ to the basic specification; neither is significant. In line with the results of Alesina and Wacziarg, the log of population enters with a negative sign, evidence of economies of scale in the provision of public goods. ${ }^{37}$

In unreported results, a number of robustness tests have been conducted, including sequentially dropping each country from the regression and using a larger sample (including countries for which no data are available on political instability). The basic results continue to hold. The same is true when the equations are estimated using random effects. In sum, it is clear from the reduced form government consumption equations that higher fractionalization leads to higher

\footnotetext{
${ }^{33}$ The same is true for ethnolinguistic fractionalization and religious fractionalization.

${ }^{34}$ In unreported results, there is no evidence that military expenditure is higher in more fractionalized countries.

${ }^{35}$ The mean of government consumption is 18.73 .

${ }^{36}$ This variable derives from Kornai (1992).

${ }^{37}$ Alesina and Wacziarg (1997) argue that the Rodrik results are spurious, based on the fact that there is a strong negative correlaction between openness and the size of a country. The external risk result, however, is robust to the inclusion of the population variable.
} 
levels of government consumption. So far, this result is consistent with both the common-pool model of weak government dominated by strong interest groups and the model of Section 3 which emphasizes political instability as the key factor which links fractionalization and government consumption. This mechanism will now be explored in some detail.

\section{Systems Estimation}

From the model of Section 3, the causality is expected to run as follows:

$$
\text { Fractionalization } \uparrow \Longrightarrow \text { Instability } \uparrow \Longrightarrow \text { Govt.Consumption } \uparrow \Longrightarrow \text { Instability } \downarrow
$$

This section treats both government consumption and political instability as endogenous variables. ${ }^{38}$ As a preliminary step in the systems estimation, OLS is used to estimate equations for government consumption and political instability, both with the other as an explanatory variable. The results can be seen in Table 2. Equations (1) and (2) of Table 2 estimate the familiar government consumption model, with instability as a regressor. The coefficient is negative and significant. All previous results hold up. The significance of instability is robust to the exclusion of fractionalization.

Equation (3) of Table 2 uses OLS to estimate an equation with instability as the dependent variable. The first question of interest is the importance of fractionalization in leading to political instability. As basic control variables, the log of GDP per capita, the urbanization rate, and the socialist dummy are all included. The literature on the determinants of political instability is not nearly as extensive as it is for government consumption. Income per capita captures the idea that instability ultimately represents the dissatisfaction of the populace. Poorer countries, defined by those with lower real income per capita, should be more prone to instability holding other factors constant. It is especially important to include this variable to avoid picking up a spurious relationship between fractionalization and instability, caused by the fact that poorer countries are more unstable, and poorer countries are more fractionalized. Countries with higher rates of urbanization may be expected to lead to more political pressures which may find a violent outlet, given appropriate conditions. ${ }^{39}$ Finally, it may be the case that, holding standard of living constant, the particular policies followed in socialist economies may lead to more inherent instability. As with all equations, the regional and decade dummies are included.

With these basic control variables alone, the coefficient on fractionalization is positive and significant suggesting that there is indeed a relationship between fractionalization and instability. ${ }^{40}$ The coefficient on income per capita is negative and highly significant, suggesting economic dissatisfaction is indeed a principal source of political instability. The coefficients on the

\footnotetext{
${ }^{38}$ In related work, Alesina, Ozler, Roubini, and Swagel (1996) estimate a systems model in which economic growth and political instability are both endogenous. Instability is defined as the propensity of government change. Alesina and Perotti (1996) treat investment and instability as endogenous, where instability is defined as an index of political unrest.

${ }^{39}$ Ades and Glaeser (1995) postulate that the direction of causality runs from political instability to urbanization.

${ }^{40}$ The results are not reported, but both ethnolinguistic fractionalization and religious fractionalization are just as significant when entered independently.
} 
urbanization rate and the socialist dummy possess the anticipated signs, but are not significant at conventional levels. The coefficient on government consumption is negative and significant suggesting that countries which devote more resources to government consumption are associated with lower levels of political instability. ${ }^{41}$

It can be concluded from the OLS results of Table 2 that there is a strong negative association between government consumption and instability. The direction of causality, however, remains to be determined. A priori, it is possible to make causality arguments in both directions. It may be the case that political instability (especially violent instability of the sort considered here) lessens the government's ability to collect tax revenue or borrow on international markets and this constrains actual government consumption to be lower than desired. An alternative hypothesis argues, in a Hobbesian manner, that the causality runs in the opposite direction with lower levels of government consumption breeding discontent among the populace which may erupt into violent political instability. The second explanation, of course, is the one provided by the model of Section 2.

An attempt to disentangle these effects will be made using Two-Stage-Least-Squares (TSLS) treating government consumption and instability as endogenous variables. If this hypothesis is correct, then the estimates from Table 2 will suffer from simultaneous equations bias. From the full set of exogenous variables, the following variables are selected as instruments for government consumption: the age dependency ratio, openness, the standard deviation of terms of trade shocks and external risk (the interaction of openness with the standard deviation of terms of trade shocks). Fractionalization, the urbanization rate and the socialist dummy are used to instrument for instability. Income per capita, as well as the regional and decade dummies are included in both equations. Basically, equations (1) and (3) of Table 2 are being re-estimated using the technique of instrumental variables, treating government consumption and instability as endogenous. This will allow for testing the validity of the hypothesized causality.

It can be seen from the first two equations of Table 3 that the results are quite favorable. The key result is that while the effect of government consumption on instability remains negative and significant, the effect of instability on government consumption is now positive and significant. Furthermore, the point estimate on fractionalization in the instability equation remains positive and significant. We can conclude, therefore, that the hypothesized chain of causation is indeed borne out by the data. Higher fractionalization leads directly to higher instability. In response, government spending rises and this has the consequent effect of leading to lower political instability. Table 3 also reports the test statistics associated with the Chi-squared test of overidentifying restrictions for each equation; this basically tests the relationship between the instruments and the error term in the structural equation. The resulting low statistics suggest that the instruments in each case are validly excluded. ${ }^{42}$ This system was also estimated by Three Stage Least Squares; the results are not reported here as they are virtually identical to the TSLS results.

\footnotetext{
${ }^{41}$ It is especially important to to remove military expenditure from government consumption in this case. In unreported results, adding military spending as a percentage of GDP to this equation yields a coefficient that is positive and significant.

${ }^{42}$ Some experimentation with different assumptions regarding excludability of the instruments was undertaken. In particular, it is conceivable that external vulnerability is an instrument for instability. The Rodrik variables, however, fail the Chi-squared test in this case.
} 
These results suggest that the effects of fractionalization on government consumption are indirect, and work through the political instability mechanism. It is also possible that there is a direct effect on government consumption, if, for example, the common pool hypothesis is believed. Equation (3) of Table 3 tests this hypothesis by incorporating fractionalization directly into the government consumption equation and engaging in TSLS estimation. The results show that the relevant coefficient is positive but completely insignificant. Thus we can conclude that there is no direct effect in operation. But there is another problem: including fractionalization directly has the effect of reducing the point estimate on instability and rendering it insignificant. The conclusion to be drawn from this is that the predictive power of fractionalization is needed to estimate instability in this equation. The government consumption equation is relatively easy to identify, given the large number of independent variables posited in the literature to influence government consumption. Identifying political instability is somewhat harder in this system, and it seems to be the case that excluding fractionalization from the government consumption equation is advisable.

Returning to the system estimated by equations (1) and (2), it is the case that an increase in fractionalization by one standard deviation leads to an increase in instability of 0.1144 , which is 0.28 of a standard deviation. An increase in government consumption by one standard deviation leads to a fall in the instability index of 0.39 units, or 0.96 of a standard deviation. Finally, an increase in instability by one standard deviation leads to a rise in the ratio of government consumption to GDP by 7.89 percentage points, corresponding to one standard deviation. ${ }^{43}$ Let us now consider the total effect of a one standard deviation increase in fractionalization: first, instability increases by 0.1144 . This in turn leads government consumption to rise by 2.203 percentage points. Finally, this causes instability to decline by 0.1102 units. As the system equilibrates, the overall effect on instability is an increase by 0.004 , or 0.01 of a standard deviation. It should also be noted that the direct effect of fractionalization on instability counteracts the indirect effect through government consumption, leaving virtually no aggregate effect on instability; this was a conclusion of the model in Section 2, for reasonable specifications of the instability function.

Table 4 repeats the TSLS specification of Table 3 , but replaces fractionalization by both ethnolinguistic fractionalization and religious fractionalization. In the instability equation, both of these variables are significant in equations (2) and (4) respectively, suggesting that ethnic and religious fractionalization independently lead to higher political instability. Similarly, the strong evidence that government consumption decreases instability remains. The only difference between this specification and that of Table 3 is that in the former, the point estimates on instability in the government consumption equation falls just outside the standard significance levels. In both equations (1) and (3) of Table 4 the p-values for instability fall to 0.12 , from 0.07 when fractionalization is used as an instrument for instability. It can therefore be concluded that it is important to take both dimensions of fractionalization into account.

Table 5 assesses robustness by considering the sensitivity of the model to a number of alternative indices of fractionalization and instability. All four alternative fractionalization indices exhibit significant positive effects on instability. Likewise, the coefficient of government consumption is always negative and significant in each case. As usual, the most fragile result is the effect of instability on government consumption. Another robustness test replaces the instability index with that of Alesina and Perotti (1996) and Perotti (1996); this index includes democracy among

${ }^{43}$ The means of government consumption and instability are 18.73 and 0.28 respectively. 
its factors under the hypothesis that instability is biased downwards in nondemocratic countries. Although the hypothesized channel is much weaker with this index, there is still evidence of it in operation. As a final robustness test, the TSLS equations are re-estimated, sequentially dropping ech country in order to test the sensitivity to outliers. ${ }^{44}$

In sum, it can be concluded that the mechanism is reasonably robust, the main deficiency being the paucity of good instruments for instability. Furthermore, it is important to take account of the two dimensions to fractionalization, ethnic and religious, in unison.

\section{CONCLUSION}

This paper has presented a hypothesis concerning the interaction between fractionalization (as measured along ethnolinguistic and religious dimensions), government consumption, and political instability. Specifically, higher fractionalization is held to lead exogenously to greater political instability. Partial insurance against the political risks engendered by the instability can be bought by raising the level of consumption. The reduced form evidence shows a strong positive relationship between fractionalization and government consumption, although it was noted that such a result was also consistent with an alternative hypothesis, that associated with a common pool model in which differing groups act in a noncooperative manner and overconsume by seizing resources from the government. In contrast to this paper, the alternative model assumes a weak government. This paper shows that endogenizing political instability is crucial and that once a system with two endogenous variables is estimated, it becomes clear that the effect of fractionalization on government consumption is indirect, via the political instability channel.

Furthermore, it is clear that governments use government consumption as a buffer against political instability. One lesson to be drawn from this paper is that it is possible for a country to reduce the level of instability, even if the country is divided into competing groups. This involves the use of government consumption. Permitting a government to increase its consumption will reduce the level of political instability, and numerous researchers have pointed out that political instability is detrimental to growth.

${ }^{44}$ These results are unreported, and are available upon request from the author. 
Table 1

OLS Government Consumption Equations*

\begin{tabular}{|c|c|c|c|c|c|c|}
\hline & (1) & (2) & (3) & (4) & $(5)$ & (6) \\
\hline & OLS & OLS & OLS & OLS & OLS & OLS \\
\hline \multirow[t]{2}{*}{ Africa Dummy } & & -5.48 & -4.03 & -5.15 & -5.64 & -7.20 \\
\hline & & $(-2.78)$ & $(-2.25)$ & $(-2.75)$ & $(-2.73)$ & $(-3.18)$ \\
\hline Latin America Dummy & & -5.21 & -5.07 & -4.96 & -5.70 & $\begin{array}{r}-6.78 \\
(5.65)\end{array}$ \\
\hline \multirow[t]{2}{*}{ East Asia Dummy } & & -9.60 & -8.39 & -9.51 & -9.84 & -9.09 \\
\hline & & $(-5.98)$ & $(-5.81)$ & $(-6.09)$ & $(-5.60)$ & $(-5.43)$ \\
\hline \multirow[t]{2}{*}{ Log GDP per Capita } & -4.15 & -4.78 & -4.60 & -4.91 & -5.74 & -6.01 \\
\hline & $(-6.29)$ & $(-6.09)$ & $(-6.04)$ & $(-6.11)$ & $(-5.96)$ & $(-6.26)$ \\
\hline \multirow[t]{2}{*}{ Age Dependency Ratio } & -1.18 & 2.59 & 1.85 & 3.36 & 3.03 & 3.30 \\
\hline & $(-0.31)$ & $(0.79)$ & $(0.56)$ & $(1.01)$ & $(0.92)$ & $(1.05)$ \\
\hline \multirow[t]{2}{*}{ Openness } & 0.008 & 0.02 & 0.02 & 0.02 & 0.02 & -0.004 \\
\hline & $(0.31)$ & $(1.06)$ & $(0.95)$ & $(1.00)$ & $(1.00)$ & $(-0.12)$ \\
\hline \multirow[t]{2}{*}{ St. Dev. of Terms of Trade } & -0.20 & -0.20 & -0.20 & -0.19 & -0.19 & -0.19 \\
\hline & $(-1.57)$ & $(-1.97)$ & $(-1.99)$ & $(-1.87)$ & $(-1.84)$ & $(-1.94)$ \\
\hline \multirow[t]{2}{*}{ External Risk } & 0.003 & 0.003 & 0.003 & 0.003 & 0.003 & 0.003 \\
\hline & $(1.70)$ & $(2.05)$ & $(2.13)$ & $(2.04)$ & $(2.06)$ & $(2.04)$ \\
\hline \multirow[t]{2}{*}{ Fractionalization } & 1.54 & 5.84 & & & 5.42 & 7.53 \\
\hline & $(0.94)$ & $(2.84)$ & & & $(2.46)$ & (2.95) \\
\hline Ethnic Fractionalization & & & $\begin{array}{r}2.78 \\
(1.92)\end{array}$ & & & \\
\hline Religious Fractionalization & & & & $\begin{array}{r}4.61 \\
(2.69)\end{array}$ & & \\
\hline Urbanization Rate & & & & & $\begin{array}{r}0.05 \\
(1.26)\end{array}$ & $\begin{array}{r}0.06 \\
(1.65)\end{array}$ \\
\hline \multirow[t]{2}{*}{ Socialist Dummy } & & & & & 1.22 & 1.35 \\
\hline & & & & & $(0.57)$ & $(0.57)$ \\
\hline Log Population & & & & & & $\begin{array}{r}-0.95 \\
(-2.40)\end{array}$ \\
\hline R-s & 0.35 & 0.44 & 0.43 & 0.44 & 0.45 & 0.46 \\
\hline $\mathrm{N}$ & 262 & 262 & 264 & 262 & 257 & 257 \\
\hline
\end{tabular}


Table 2

Government Consumption and Political Instability Equations*

\begin{tabular}{|c|c|c|c|}
\hline & (1) & $(2)$ & (3) \\
\hline \multirow[t]{3}{*}{ Dependent Variable } & Government & Government & Instability \\
\hline & Consumption & Consumption & \\
\hline & OLS & OLS & OLS \\
\hline \multirow[t]{2}{*}{ Instability } & -1.86 & -2.06 & \\
\hline & $(-1.94)$ & $(-2.14)$ & \\
\hline \multirow[t]{2}{*}{ Government Consumption } & & & -0.02 \\
\hline & & & $(-3.86)$ \\
\hline \multirow[t]{2}{*}{ Africa Dummy } & -2.98 & -5.62 & -0.31 \\
\hline & $(-1.91)$ & $(-2.90)$ & $(-3.03)$ \\
\hline \multirow[t]{2}{*}{ Latin America Dummy } & -4.59 & -5.03 & -0.01 \\
\hline & $(-4.24)$ & $(-4.74)$ & $(-0.16)$ \\
\hline \multirow[t]{2}{*}{ East Asia Dummy } & -7.19 & -9.11 & -0.0003 \\
\hline & $(-5.77)$ & $(-6.03)$ & $(-0.002)$ \\
\hline \multirow[t]{2}{*}{ Fractionalization } & & 6.24 & 0.37 \\
\hline & & $(3.03)$ & $(2.73)$ \\
\hline \multirow[t]{2}{*}{ Log GDP per Capita } & -4.76 & -4.86 & -0.22 \\
\hline & $(-6.00)$ & $(-6.22)$ & $(-4.45)$ \\
\hline \multirow[t]{2}{*}{ Age Dependency Ratio } & 2.16 & 2.84 & \\
\hline & $(0.65)$ & $(0.87)$ & \\
\hline \multirow[t]{2}{*}{ Openness } & 0.01 & 0.02 & \\
\hline & $(0.65)$ & $(0.91)$ & \\
\hline \multirow[t]{2}{*}{ Sd. Dev. of Terms of Trade } & -0.18 & -0.17 & \\
\hline & $(-1.79)$ & $(-1.86)$ & \\
\hline \multirow[t]{2}{*}{ External Risk } & 0.003 & 0.003 & \\
\hline & (1.99) & $(1.89)$ & \\
\hline \multirow[t]{2}{*}{ Urbanization Rate } & & & 0.002 \\
\hline & & & $(1.30)$ \\
\hline \multirow[t]{2}{*}{ Socialist Dummy } & & & 0.16 \\
\hline & & & $(1.49)$ \\
\hline R-sq & 0.44 & 0.45 & 0.17 \\
\hline $\mathrm{N}$ & 264 & 262 & 264 \\
\hline
\end{tabular}


Table 3

Fractionalization in TSLS Model

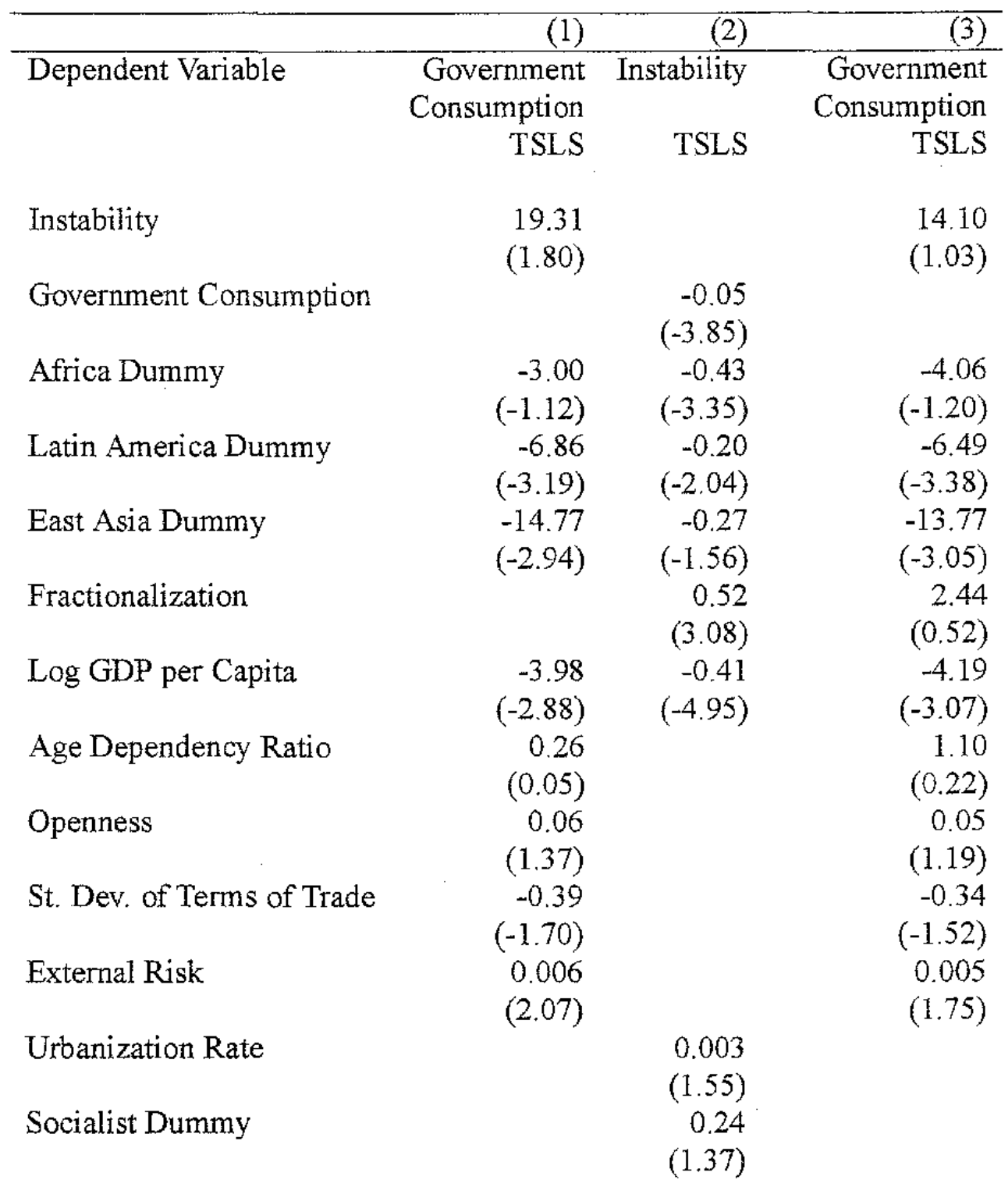

Chi-Sq

0.57

1.67

0.49

* Robust standard errors used; t-statistics in parentheses. Decade dummies included. 
Table 4

Ethnic and Religious Fractionalization in a TSLS Model*

\begin{tabular}{|c|c|c|c|c|}
\hline- & (1) & (2) & (3) & (4) \\
\hline Dependent Variable & $\begin{array}{l}\text { Government } \\
\text { Consumption }\end{array}$ & Instability & $\begin{array}{l}\text { Government } \\
\text { Consumption }\end{array}$ & Instability \\
\hline & TSLS & TSLS & TSLS & TSLS \\
\hline Instability & $\begin{array}{r}14.71 \\
(1.55)\end{array}$ & & $\begin{array}{l}21.41 \\
(1.57)\end{array}$ & \\
\hline Government Consumption & & $\begin{array}{r}-0.06 \\
(-3.79)\end{array}$ & & $\begin{array}{r}-0.05 \\
(-3.78)\end{array}$ \\
\hline Africa Dummy & $\begin{array}{r}-2.87 \\
(-1.25)\end{array}$ & $\begin{array}{r}-0.33 \\
(-2.68)\end{array}$ & $\begin{array}{r}-2.97 \\
(-1.04)\end{array}$ & $\begin{array}{r}-0.37 \\
(-2.91)\end{array}$ \\
\hline Latin America Dummy & $\begin{array}{r}-6.36 \\
(-3.39)\end{array}$ & $\begin{array}{r}-0.21 \\
(-2.02)\end{array}$ & $\begin{array}{r}-7.07 \\
(-2.99)\end{array}$ & $\begin{array}{r}-0.18 \\
(-1.81)\end{array}$ \\
\hline East Asia Dummy & $\begin{array}{l}-13.03 \\
(-3.05)\end{array}$ & $\begin{array}{r}-0.21 \\
(-1.24)\end{array}$ & $\begin{array}{l}-15.45 \\
(-2.72)\end{array}$ & $\begin{array}{r}-0.24 \\
(-1.38)\end{array}$ \\
\hline Ethnic Fractionalization & & $\begin{array}{r}0.31 \\
(2.46)\end{array}$ & & \\
\hline Religious Fractionalization & & & & $\begin{array}{r}0.33 \\
(2.45)\end{array}$ \\
\hline Log GDP per Capita & $\begin{array}{r}-4.04 \\
(-3.33)\end{array}$ & $\begin{array}{r}-0.39 \\
(-4.43)\end{array}$ & $\begin{array}{r}-3.89 \\
(-2.53)\end{array}$ & $\begin{array}{r}-0.44 \\
(-5.10)\end{array}$ \\
\hline Age Dependency Ratio & $\begin{array}{r}1.23 \\
(0.26)\end{array}$ & & $\begin{array}{r}0.07 \\
(0.01)\end{array}$ & \\
\hline Openness & $\begin{array}{r}0.04 \\
(1.30)\end{array}$ & & $\begin{array}{r}0.06 \\
(1.29)\end{array}$ & \\
\hline Sd. Dev. of Terms of Trade & $\begin{array}{r}-0.35 \\
(-1.70)\end{array}$ & & $\begin{array}{r}-0.41 \\
(-1.62)\end{array}$ & \\
\hline External Risk & $\begin{array}{r}0.006 \\
(2.06)\end{array}$ & & $\begin{array}{l}0.007 \\
(1.96)\end{array}$ & \\
\hline Urbanization Rate & & $\begin{array}{r}0.003 \\
(1.39)\end{array}$ & & $\begin{array}{r}0.004 \\
(1.84)\end{array}$ \\
\hline Socialist Dummy & & $\begin{array}{r}0.23 \\
(1.31)\end{array}$ & & $\begin{array}{r}0.23 \\
(1.36)\end{array}$ \\
\hline Chi-Sq & 0.41 & 1.48 & 0.87 & 2.52 \\
\hline
\end{tabular}


Table 5

Other Definitions of Fractionalization*

- $\quad$ (From Equations (1) and (2) of Table 3)

\begin{tabular}{lrr}
\hline Alternative Indices & & \\
Index 1 & Government Consumption & Instability \\
0.43 & -0.06 & 10.89 \\
$(3.14)$ & $(-3.79)$ & $(1.60)$ \\
& & \\
Index 2 & Government Consumption & Instability \\
0.50 & -0.09 & -0.05 \\
$(2.44)$ & $(-2.48)$ & $(-0.02)$ \\
& & \\
Index 3 & Government Consumption & Instability \\
0.82 & -0.08 & 10.01 \\
$(2.65)$ & $(-2.17)$ & $(1.58)$ \\
& & \\
Index 4 & Government Consumption & Instability \\
0.34 & -0.06 & 20.48 \\
$(2.49)$ & $(-3.80)$ & $(1.65)$ \\
& & \\
Fractionalization & Government Consumption & Alesina-Perotti \\
0.53 & -0.05 & 6.23 \\
$(1.54)$ & $(-1.65)$ & $(1.65)$ \\
\hline
\end{tabular}

*The alternative indices refer to other indices of ethnic and religious fractionalization, as defined in the text. Estimates and t-statistics are reported for the index itself and the resulting values for instability and government consumption in the TSLS regression. 


\section{References}

Ades, Alberto F., and Edward L. Glaeser, 1995, "Trade and Circuses: Explaining Urban Giants," Quarterly Journal of Economics, Vol. 110, pp. 195-227.

Alesina, Alberto, Reza Baqir, and William Easterly, 1997, "Public Goods and Ethnic Divisions," (unpublished; Washington: World Bank).

Alesina, Alberto, Sule Ozler, Nouriel Roubini, and Phillip Swagel, 1996, "Political Instability and Economic Growth," Journal of Economic Growth, Vol.1, pp. 189-211.

Alesina, Alberto and Roberto Perotti, 1996, "Income Distribution, Political Instability, and Investment," European Economic Review, Vol. 40, pp.1203-28.

Alesina, Alberto and Enrico Spolaore, 1995, "On the Number and Size of Nations," NBER Working Paper No. 5050 (Cambridge, Massachusetts: National Bureau of Economic Research).

Alesina, Alberto and Romain Wacziarg, 1997, "Openness, Country Size, and Government," (unpublished; Cambridge: Harvard University).

Barrett, David B., eds., 1982, World Christian Encyclopedia (New York: Oxford University Press).

Barro, Robert J., 1991, "Economic Growth in a Cross-Section of Countries," Quarterly Journal of Economics, Vol. 106, pp. 327-69.

— 1996a, "Determinants of Economic Growth: A Cross-Country Empirical Study," NBER Working Paper No. 5698 (Cambridge, Massachusetts: National Bureau of Economic Research).

—_, 1996b, "Determinants of Democracy," (unpublished; Cambridge: Harvard University).

Barro, Robert J., and Gary S. Becker, 1989, "Fertility Choice in a Model of Economic Growth," Econometrica, Vol. 57, pp. 481-501.

Barro, Robert J., and Xavier Sala-i-Martin, 1995, Economic Growth (New York: McGraw Hill).

Becker, Gary S., and Robert J. Barro, 1988, "A Reformulation of the Economic Theory of Fertility," Quarterly Journal of Economics, Vol. 103, pp. 1-25.

Blomberg, S. Brock, 1996, "Growth, Political Instability, and the Defence Burden," Economica, Vol. 63, pp. 649-72. 
Canning, David, and Marianne Fay, 1993, "Growth and Infrastructure," (unpublished; New York: Columbia University).

Commander, Simon, Hamid R. Davoodi and Une J. Lee, 1997, "The Causes and Consequences of Government for Growth and Well-Being," World Bank Policy Research Working Paper No. 1785 (Washington: World Bank).

Easterly, William and Ross Levine, 1997, "Africa's Growth Tragedy: Politics and Ethnic Divisions," Quarterly Journal of Economics, Vol. 112, pp. 1203-50.

Gupta, Dipak K., 1990, The Economics of Political Violence: the Effect of Political Instability on Economic Growth (New York and London: Greenwood Press and Praeger).

Heller, Peter S. and Jack Diamond, 1990, International Comparisons of Government Expenditure Revisited: the Developing Countries, 1975-86, IMF Occasional Paper No. 69 (Washington: International Monetary Fund).

Hibbs, Douglas A., 1973, Mass Political Violence: A Cross-Sectional Analysis New York: Wiley and Sons).

Komai, Janos, 1992, The Socialist System: The Political Economy of Communism (Princeton: Princeton University Press).

Kraay, Aart and Caroline van Rijckeghem, 1995, "Employment and Wages in the Public Sector: A Cross-Country Study," IMF Working Paper 95/70 (Washington: International Monetary Fund).

Kuijs, Louis, 2000, "The Impact of Ethnic Heterogeneity on the Quantity and Quality of Public Spending," IMF Working Paper 00/49 (Washington: International Monetary Fund).

Lane, Philip R. and Aaron Tornell, 1996, "Power, Growth, and the Voracity Effect," Journal of Economic Growth, Vol. 1, pp. 213-41.

La Porta, Rafael, Florencio Lopez de Silanes, Andrei Shleifer, and Robert Vishny, 1998, "The Quality of Government," NBER Working Paper No. 6727 (Cambridge, Massachusetts: National Bureau of Economic Research).

Lindauer, David L., 1988, "The Size and Growth of Government Spending," World Bank Policy, Planning, and Research Working Paper No. 44 (Washington: World Bank).

Londregan, John B. and Keith T. Poole, 1990, "Poverty, the Coup Trap, and the Seizure of Executive Power," World Politics, Vol. 92, pp. 1-24. 
McGuire, Martin C. and Mancur Olson, 1996, "The Economics of Autocracy and Majority Rule: The Invisible Hand and the Use of Force," Journal of Economic Literature, Vol. 34, pp. 72-96.

Mauro, Paulo, 1995, "Corruption and Growth," Quarterly Journal of Economics, Vol. 110, pp. $681-712$.

Muller, Siegfried H., 1964, The World's Living Languages: Basic Facts of Their Structure, Kinship, and Number of Speakers (New York: Ungar).

Obstfeld, Maurice, 1990, "Intertemporal Dependence, Impatience, and Dynamics," Journal of Monetary Economics, Vol. 26, pp. 45-75.

Perotti, Roberto, 1996, "Growth, Income Distribution, and Democracy: What the Data Say," Journal of Economic Growth, Vol. 1, pp. 153-91.

Ram, Rati, 1987, "Wagner's Hypothesis in Time-Series and Cross-Section Perspectives: Evidence from Real Data for 115 Countries," The Review of Economics and Statistics, Vol. 69, pp. 194-204.

Rodrik, Dani, 1995, "International Trade and Big Government," (unpublished; New York: Columbia University).

—_, 1996, "Why Do More Open Economies Have Bigger Governments?" NBER Working Paper No. 5537 (Cambridge, Massachusetts: National Bureau of Economic Research).

_._. 1997a, "Trade, Social Insurance, and the Limits to Globalization," NBER Working Paper No. 5905 (Cambridge, Massachusetts: National Bureau of Economic Research).

- 1997b, "What Drives Public Employment?," NBER Working Paper No. 6141 (Cambridge, Massachusetts: National Bureau of Economic Research).

Roberts, Janet, 1962, "Sociocultural change and communication problems," in Study of the Role of Second Languages in Asia, Africa, and Latin America, ed. by F. Rice (Washington: Center for Applied Linguistics of the Modern Language Association of America).

Sala-i-Martin, Xavier, 1997, "I Just Ran Four Million Regressions," (unpublished; New York: Columbia University).

Iait, Alan A. and Peter. S. Heller, 1982, International Comparisons of Government Spending, IMF Occasional Paper No. 10 (Washington: International Monetary Fund). 
Taylor, Charles Lewis and Michael C. Hudson, 1972, World Handbook of Political and Social Indicators (New Haven: Yale University Press, 2nd ed.).

Tornell, Aaron. and Philip R. Lane, 1998, "Are Windfalls a Curse? A Non-Representative Agent Model of the Current Account," Journal of International Economics, Vol. 44, pp. 83-112.

Uzawa, Hirofumi, 1968, "Time Preference, the Consumption Function, and Optimum Asset Holdings," in Capital and Growth: Papers in Honour of Sir John Hicks, ed. by J. Wolfe (Chicago: Aldine).

Vanieris, Yiannis P., and Dipak K. Gupta, 1986, "Income Distribution and Socio-Political Instability as Determinants of Savings; A Cross-Sectional Model," Journal of Political Economy, Vol. 96, pp. 873-83.

Velasco, Andres, 1994, "A Model of Endogenous Fiscal Deficits and Delayed Fiscal Reforms," (unpublished; New York: New York University).

- 1995, "The Common Property Approach to the Political Economy of Fiscal Policy,"(unpublished; New York: New York University).

World Bank, 1997, World Development Report: The State in a Changing World. (Washington: Oxford University Press). 